\title{
Pengaruh pelatihan pemeliharaan kesehatan gigi pada guru sekolah dasar sistem full day terhadap perubahan status kebersihan mulut siswa
}

\author{
Anne Agustina Suwargiani, Riana Wardani, Netty Suryanti, Asty Samiaty Setiawan \\ Departemen IImu Kesehatan Gigi Masyarakat, Fakultas Kedokteran Gigi, Universitas Padjadjaran, Bandung, Jawa Barat, Indonesia \\ JI Sekeloa Selatan No 1, Bandung, Jawa Barat, Indonesia; e-mail: anne.agustina@fkg.unpad.ac.id
}

Submisi: 1 Agustus 2016; Penerimaan: 27 September 2016; Publikasi online: 28 April 2017

\begin{abstract}
ABSTRAK
Usia Sekolah Dasar merupakan usia yang tepat untuk mengajarkan teknik menyikat gigi yang baik dan benar, karena pada usia ini anak sedang dalam memasuki periode gigi campuran dan sudah harus mampu menyikat gigi baik dan benar. Penerapan penyikatan gigi di Sekolah Dasar dengan sistem full day sangat diperlukan, mengingat waktu anak di sekolah lebih lama dan melewati waktu makan siang sehingga anak harus mampu menjaga kesehatan giginya sendiri. Penerapan tersebut sangat membutuhkan peran guru. Tujuan penelitian yaitu menganalisis pengaruh pelatihan penyikatan gigi pada guru terhadap status kebersihan mulut siswa. Mixed methode terdiri dari tahap penelitian kuantitatif dengan pemberian kuisioner pengetahuan, sikap dan tindakan guru setelah pelatihan penyikatan gigi dan keterampilan menyikat gigi siswa diukur melalui status kebersihan mulut (OHIS green Vermillion) dan tahap penelitian kualitatif dengan melakukan observasi menggunakan cek list observasi untuk mengetahui faktor penghambat transfer hasil pelatihan pada siswa. Metode penelitian deskriptif analitik. Sampel penelitian diambil dari seluruh populasi, dimana semua guru diambil sebagai sampel penelitian. Hasil penelitian melalui uji korelasi linier menunjukkan hubungan antara pengetahuan, sikap dan tindakan terhadap status kebersihan gigi dan mulut adalah sedang (R:0.43). Prosentase sumbangan variabel pengetahuan, sikap dan tindakan guru yang digunakan dalam model terlihat pada nilai $R$ square yaitu sebesar $18,5 \%$, sedangkan sisanya sebesar $81,5 \%$ dipengaruhi oleh variabel lain yang tidak dimasukkan ke dalam penelitian. ada pengaruh signifikan tindakan terhadap status kebersihan mulut siswa, namun tidak ada pengaruh secara signifikan pengetahuan dan sikap terhadap status kebersihan mulut siswa. Faktor internal guru dan siswa serta faktor eksternal berupa penyediaan fasilitas. Simpulan penelitian mixed methode ini adalah pelatihan penyikatan gigi pada guru sekolah dasar sistem full day berpengaruh sebesar $18,5 \%$, terhadap status kebersihan mulut siswa. Faktor penghambat menerapkan hasil pelatihan yaitu faktor internal dan eksternal guru dan siswa.
\end{abstract}

Kata kunci: guru; kebersihan mulut; pelatihan

ABSTRACT: Effect of dental care training on primary full day school teachers towards student's oral hygiene status alteration. Elementary School age is the most appropriate age of having proper toothbrush technique teaching, because at this age children are entering mixed dentition period, so they should be able to do proper toothbrush technique. The practice of brushing teeth in full-day system elementary school is fundamental because most of the student's time was spent in school, and they were also having lunch there, so the students should have been able to maintain the health of their teeth, which can only be implied with active role of teachers. The objective of this study was to analyze the effect of dental care training towards student's oral hygiene status alteration. The method of this research was mixed methods that consisted of quantitative research phase that was done by providing questionnaires about knowledge, attitudes and behaviours of teachers after toothbrushing training, and the student's toothbrushing skill that was measured through the oral hygiene status (OHIS green Vermillion). Whilst the phase of qualitative research was done by observation using observation checklist to identified the inhibiting factors of delivering the training results to the students. The sampling technique was total sampling, with all the teachers were taken as samples. The results from linear regression test showed that there was a moderate relation between the training effect towards student's oral hygiene status alteration $(R: 0.43)$. The contribution percentage of teacher's knowledge, attitude and action variable used in the research model was seen on $R$ square value that was $18.5 \%$, whilst on the value of $81.5 \%$ was influenced by other variables not included in the research. This value was the result of students' variety perceptions about toothbrushing; the unconducive situation of the classrooms; difficulties of teachers to delivered the counselling materials; teacher's feeling of knowledge limitations; and forgetfulness of the usage of the dental model replica. There was a significant effect of the action towards the oral hygiene status of the students, but there was no significant influence of knowledge and attitude towards the oral hygiene status of the students. Conclusions: Dental care training on full-day primary school teachers did not significantly change their knowledge and attitude of toothbrushing, but continuous and proper practice after training, however, gave significant effect on student's oral hygiene status. Inhibiting factors of alteration were coming from internal environment of both teachers and students, and also due to lack of facilities.

Keywords: teacher; oral hygiene; dental care training 
Majalah Kedokteran Gigi Indonesia. April 2017; 3(1): 15 - 22

ISSN 2460-0164 (print)

ISSN 2442-2576 (online)

\section{PENDAHULUAN}

Hasil Riskesdas tahun 2007 menerangkan 90,7\% masyarakat menggosok gigi masih pada waktu yang kurang tepat yaitu setiap hari pada waktu mandi pagi dan atau sore. Proporsi masyarakat yang menggosok gigi setiap hari sesudah makan pagi hanya $12,6 \%$ dan sebelum tidur malam hanya $28,7 \%$. Sebagian besar penduduk umur 10 tahun ke atas $(91,1 \%)$ mempunyai kebiasaan menggosok gigi setiap hari, namun pada saat yang tepat yaitu setelah makan pagi hanya 11,8 dan sebelum tidur hanya 25\%. ${ }^{1}$ Hasil riskesdas 2013 menunjukkan bahwa kesalahan menyikat gigi merata di semua kelompok umur 10 tahun ke atas. ${ }^{2}$

Sikat gigi sebaiknya dilakukan paling sedikit sehari dua kali yaitu setelah makan pagi dan sebelum tidur, ${ }^{1}$ yang seharusnya menyikat gigi akan lebih baik apabila dilakukan setiap sesudah makan. ${ }^{3}$ Kondisi tersebut dapat dikurangi dengan melakukan pencegahan berupa pemberian peningkatan pengetahuan, sikap dan perilaku di bidang kesehatan gigi. Salah satu cara yang paling mudah dan memungkinkan serta sesuai dengan program UKGS adalah penerapan sikat gigi di sekolah dengan dibantu oleh guru. ${ }^{4}$ Guru dapat berperan sebagai pendidik kesehatan hanya jika mereka memiliki pengetahuan, sikap dan tindakan yang baik di bidang kesehatan gigi. ${ }^{5}$

Pelatihan kesehatan gigi dapat meningkatkan keterampilan dan sumber daya informasi di masyarakat, sehingga kader yang dalam hal ini guru dapat berperan dalam meningkatkan akses informasi mengenai kesehatan gigi. ${ }^{6}$ Beberapa hasil penelitian menyebutkan bahwa penyuluhan dan pelatihan pada kader memberikan hasil yang efektif dalam meningkatkan pengetahuan, sikap dan perilaku, $, 7,7,8$ sehingga kader mampu memberikan penyuluhan dan memotivasi masyarakat untuk dapat berperilaku sehat. ${ }^{8}$ Keadaan tersebut di atas menunjukkan perlu ditingkatkannya program usaha kesehatan gigi di sekolah melalui upaya pemberian pelatihan pada guru mengenai cara menyikat gigi yang benar dengan menggunakan metode pembelajaran yang baik dan benar sehingga guru dapat mentransfernya pada anak didik dengan baik.

Sekolah merupakan tempat penting untuk melakukan upaya peningkatan kesehatan. Pesan peningkatan kesehatan dapat ditekankan pada masa-masa sekolah, sehingga memungkinkan mereka untuk mengembangkan sikap dan keterampilan yang menetap sepanjang umurnya. ${ }^{9}$ Sekolah dengan sistem full day merupakan sekolah yang sangat memerlukan perhatian khusus di bidang kesehatan gigi. Sekolah dengan sistem full day adalah sekolah dengan proses belajar mengajar yang dilaksanakan dari pagi hingga sore hari, dimulai sesudah makan pagi dan melewati waktu makan siang. sehingga diperlukan penyikatan gigi untuk mencegah terjadinya penyakit gigi dan gusi.

Uraian di atas mengarahkan pada perlunya melakukan penelitian mixed methode mengenai pengaruh pelatihan penyikatan gigi pada guru Sekolah Dasar dengan sistem full day terhadap keterampilan pengajaran penyikatan gigi pada anak didik dan meneliti faktor-faktor apa saja yang menghambat dalam pelaksanaan hasil pelatihan untuk pertama kalinya. Tujuan penulisan yaitu menganalisis pengaruh pelatihan penyikatan gigi pada guru sekolah dasar dengan sistem full day terhadap status kebersihan mulut siswa dan mengetahui faktor-faktor apa yang menghambat pelaksanaan hasil pelatihan.

\section{METODE PENELITIAN}

Rancangan penelitian mixed method tipe explanatory, dimana dilakukan penelitian kuantitatif terlebih dahulu dan dilanjutkan dengan kualitatif. ${ }^{10}$ Penelitian dilakukan di SD Arrafi Baleendah Kabupaten Bandung, tahun 2015. Unit analisis adalah keterampilan guru dalam mentransfer hasil pelatihan kepada anak didik. Populasi penelitian adalah seluruh guru pada sekolah dan semua murid kelas 1 dengan sistem full day. Sampel penelitian diambil dari seluruh populasi penelitian, dimana semua guru di sekolah dan semua murid kelas satu dijadikan subjek penelitian. ${ }^{10}$

Pengumpulan data dilakukan dengan memberikan kuisioner sebelum dan sesudah pelatihan kemudian melakukan observasi dengan menggunakan check list observasi. Analisis data untuk teknik kuantitatif menggunakan distribusi frekuensi relatif dan dilanjutkan dengan pengkategorian Arikunto ${ }^{11}$ yaitu: kategori baik $(76 \%-100 \%)$, kriteria 
cukup $(60 \%-75 \%)$, dan kriteria kurang (kurang dari $60 \%)$, kemudian dilakukan uji regresi berganda. Analisis data untuk teknik kualitatif dengan tahapan sebagai berikut: 1) mentranskripkan, 2) koding, 3) pengkategorian dan 4) penyajian data. ${ }^{12}$ Penelitian mengacu pada empat prinsip etik penelitian yang dipersyaratkan oleh komite etik penelitian Fakultas Kedokteran Universitas Padjajaran menghormati harkat dan martabat subjek, menghormati kebebasan subjek, tidak merugikan dan menerapkan prinsip keadilan, dan telah mendapatkan pengesahan layak etik nomor. ${ }^{11}$

Alat ukur penilaian status kebersihan mulut dengan menggunakan formulir pemeriksaan yang mengacu pada OHIS green and vermilion. ${ }^{13}$ Penilaian faktor faktor yang menghambat pelaksanaan hasil pelatihan dinilai melalui faktor internal dan eksternal. faktor penghambat internal dan eksternal diklasifikasikan mengacu pada pengertian faktor eksternal yaitu persentuhan, repetisi, dan penguatan dan faktor internal yaitu informasi, keterampilan intelektual dan strategi/ metode belajar dalam perubahan perilaku. ${ }^{14}$

\section{HASIL PENELITIAN}

Hasil penelitian penelitian mixed methode terbagi menjadi dua yaitu metode kuantitatif berupa pengetahuan, sikap dan tindakan guru serta status kebersihan mulut (OHI-S) disajikan pada Tabel 1 sampai dengan Tabel 3 dan Tabel 7. Metode kuantitatif adalah hasil observasi penerapan di lapangan disajikan pada Tabel 4 sampai dengan Tabel 6 .
Hasil kuisioner pengetahuan mengenai sikat gigi dan pemeliharaan gigi menunjukkan pengetahuan rata rata pada kriteria baik. Meskipun ada dua indikator yang berada pada kriteria cukup baik. Hasil kuisioner sikap setelah pelatihan mengenai sikat gigi dan pemeliharaan gigi menunjukkan adanya pernyataan positif dan pernyataan negatif. Rata-rata sikap setelah pelatihan berada pada kriteria baik.

Tindakan guru setelah pelatihan berada pada kategori baik dan cukup baik, dengan proporsi yang seimbang. Tindakan guru dalam menyikat gigi masih belum sesuai dengan target yang diinginkan yaitu pada target dengan kriteria baik.

Status kebersihan mulut siswa setelah guru sekolah mendapat pelatihan pemeliharaan kesehatan gigi mengalami peningkatan status kebersihan mulutnya. Peningkatan rata-rata naik pada kriteria baik.

Pemodelan pelatihan penyikatan gigi terhadap status kebersihan mulut, menunjukkan angka $R$ $0,430^{\mathrm{a}}$, R square 0,185 , tingkatkesalahan 0,39 . Angka $\mathrm{R}$ sebesar 0,430 . Nilai ini berdasarkan sugiyono menunjukkan bahwa hubungan antara pengetahuan, sikap dan tindakan terhadap status kebersihan gigi dan mulut adalah sedang. ${ }^{10}$ Prosentase sumbangan variabel pengetahuan, sikap dan tindakan guru yang digunakan dalam model terlihat pada nilai $\mathrm{R}$ square yaitu sebesar $18,5 \%$, sedangkan sisanya sebesar $81,5 \%$ dipengaruhi oleh variabel lain yang tidak dimasukkan ke dalam penelitian. Ukuran banyaknya kesalahan regresi 0,40 menunjukkan model regresi baik, karena nilainya sangat rendah dan mendekati nilai $y$.

Tabel 1. Pengetahuan guru setelah pelatihan

\begin{tabular}{llll}
\hline \multicolumn{1}{c}{ Pengetahuan } & $\mathrm{F}$ & $\%$ & Kriteria \\
\hline Cara membersihkan plak & 27 & 90 & Baik \\
Kebiasaan yang baik & 30 & 100 & Baik \\
Waktu yang tepat untuk menyikat gigi & 30 & 100 & Baik \\
Jenis makanan yang tidak mudah merusak gigi & 20 & 66,7 & Cukup Baik \\
Jajanan yang tidak merusak gigi & 30 & 100 & Baik \\
Permukaan gigi yang harus disikat & 30 & 100 & Baik \\
Fluor dapat mencegah gigi berlubang & 20 & 66,7 & Cukup Baik \\
Proses terjadinya lubang gigi & 23 & 76,7 & Baik \\
Yang tidak termasuk gejala gigi berlubang & 23 & 76,7 & Baik \\
\hline
\end{tabular}


Majalah Kedokteran Gigi Indonesia. April 2017; 3(1): 15 - 22

ISSN 2460-0164 (print)

ISSN 2442-2576 (online)

Tabel 2. Sikap guru setelah pelatihan

\begin{tabular}{lccl}
\hline \multicolumn{1}{c}{ Sikap } & $\%$ & Pernyataan & Kriteria \\
\hline Adanya gigi berlubang yang menimbulkan sakit & 100 & Positif & Baik \\
Keinginan melakukan penambalan gigi berlubang & 100 & Positif & Baik \\
Perasaan berkurangnya penampilan apabila ada gigi berlubang & 70 & Positif & Baik \\
Persetujuan pentingnya kontrol ke dokter gigi enam bulan sekali & 93,3 & Positif & Baik \\
Persetujuan untuk tidak ke dokter gigi kalau tidak sakit & 6,7 & Negatif & Kurang baik \\
Kebiasaan menyikat gigi hanya pada saat mandi & 23,3 & Negatif & Baik \\
Persetujuan menyikat gigi malam tidak harus dilakukan & 86,7 & Negatif & Kurang Baik \\
$\begin{array}{l}\text { Pemakaian sikat gigi secara bersama-sama } \\
\text { Pemilihan makanan kacang kacangan yang lebih baik untuk gigi }\end{array}$ dibanding permen dan makanan manis & 90 & Negatif & Kurang Baik \\
\hline
\end{tabular}

Tabel 3. Tindakan guru setelah pelatihan

\begin{tabular}{lccl}
\hline \multicolumn{1}{c}{ Tindakan } & $\mathrm{F}$ & $\%$ & Kategori \\
\hline Menyikat gigi Malam hari sebelum tidur & 26 & 86,7 & Baik \\
Menyikat gigi sesudah sarapan menyikat gigi & 24 & 80 & Baik \\
Menyikat gigi menggunakan pasta gigi yang mengandung fluor & 30 & 100 & Baik \\
Menyikat gigi depan rahang atas & 17 & 56,7 & Cukup Baik \\
Menyikat gigi depan rahang bawah & 14 & 46,7 & Cukup Baik \\
Menyikat gigi belakang rahang atas permukaan bukal & 24 & 80 & Baik \\
Menyikat gigi belakang rahang atas permukaan lingual & 19 & 63,3 & Cukup Baik \\
Menyikat gigi belakang pada permukaan kunyah & 20 & 66,7 & Cukup Baik \\
\hline
\end{tabular}

Tabel 4. Peningkatan status kebersihan mulut siswa

\begin{tabular}{cccccc}
\hline \multirow{2}{*}{ Kriteria } & Skala & \multicolumn{2}{c}{ Sebelum } & \multicolumn{2}{c}{ Sesudah } \\
\cline { 3 - 6 } & & $\mathrm{F}$ & $\%$ & $\mathrm{~F}$ & $\%$ \\
\hline Baik & $0,0-0,6$ & 24 & 80 & 29 & 96,7 \\
Sedang & $0,7-1,8$ & 6 & 20 & 1 & 3,3 \\
Buruk & $1,9-3$ & 0 & 0,0 & 0 & 0 \\
\hline Total & & 30 & 100 & 30 & 100 \\
\hline
\end{tabular}

Tabel 5. Pemodelan pelatihan penyikatan gigi terhadap status kebersihan mulut

\begin{tabular}{cccc}
\hline Model & $\mathrm{R}$ & $R$ Square & Tingkat kesalahan \\
\hline 1 & $0,430^{\mathrm{a}}$ & 0,185 & 0,39 \\
\hline
\end{tabular}

Tabel 6. Hasil uji pengaruh variabel hasil pelatihan secara bersama-sama terhadap status kebersihan mulut siswa

\begin{tabular}{cccc}
\hline Model & df & $F$ & $\begin{array}{c}\text { Signifikansi } \\
95 \%\end{array}$ \\
\hline Regression & 3 & 1,962 &, $144^{\mathrm{b}}$ \\
\hline
\end{tabular}

Hasil uji pengaruh variabel hasil pelatihan secara bersama sama terhadap status kebersihan mulut siswa menunjukkan nilai signifikansi 0,144 nilai tersebut lebih besar dari derajat kepercayaan sebesar 0,05 , menunjukkan tidak ada pengaruh secara signifikan hasil pelatihan pada guru yang diukur melalui pengetahuan, sikap dan tindakan secara bersama sama terhadap status kebersihan mulut siswa

Tabel 7 menunjukkan hasil perhitungan pengaruh variabel secara parsial, hasilnya yaitu ada pengaruh signifikan tindakan terhadap status kebersihan mulut siswa, namun tidak ada pengaruh secara signifikan pengetahuan dan sikap terhadap status kebersihan 
mulut siswa. Koefisien regresi pengetahuan dan tindakan bernilai positif artinya pada saat pengetahuan guru meningkat maka nilai indeks OHI-S akan mengalami penurunan, sedangkan untuk koefisien regresi sikap bernilai negatif artinya pada saat sikap guru bergerak ke arah negatif maka nilai OHI-S akan mengalami kenaikan.

Tabel 7. Hasil uji pengaruh variabel hasil pelatihan secara parsial terhadap status kebersihan mulut siswa

\begin{tabular}{lcc}
\hline \multicolumn{1}{c}{ Variabel } & Nilai T & Nilai Signifikansi \\
\hline & 0,137 & 0,892 \\
Pengetahuan & 0,831 & 0,414 \\
Sikap & $-0,217$ & 0,830 \\
Tindakan & 2,369 & 0,026 \\
\hline
\end{tabular}

Tabel 8. Transkrip observasi kesulitan pelaksanaan di lapangan
Tabel 8 merupakan hasil observasi yang dilakukan pada saat pelaksanaan hasil dari pelatihan yang dilakukan oleh guru. Observasi di atas difokuskan pada hal hal yang terlihat mempersulit pelaksanaan di lapangan baik dari sisi guru maupun dari sisi siswa, dengan tujuan untuk melengkapi hasil penelitian kuantitatif.

Tabel 9 menunjukkan bahwa apabila dimasukkan ke dalam kode faktor-faktor yang mempengaruhi perilaku, hasil observasi menunjukkan hasil pelatihan banyak dipengaruhi oleh faktor internal baik dari siswa dan guru yaitu memerlukan persentuhan, repetisi, dan penguatan terhadap seseorang serta faktor eksternal yaitu peningkatan informasi dan keterampilan intelektual dan ketersediaan fasilitas.

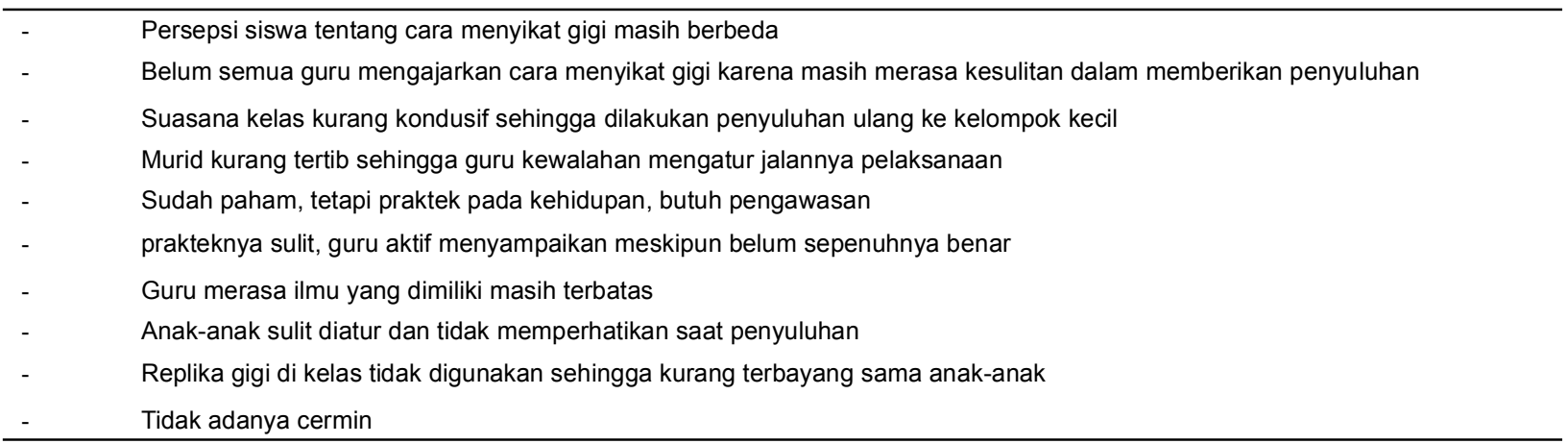

Tabel 9. Coding observasi penghambat transfer hasil pelatihan pada pelaksanaan di lapangan

- Persepsi siswa tentang cara menyikat gigi masih berbeda: tergolong faktor internal siswa memerlukan persentuhan, repetisi, dan penguatan terhadap seseorang, Faktor perilaku yaitu perilaku seseorang atau masyarakat tentang kesehatan ditentukan oleh pengetahuan dan petugas kesehatan, faktor eksternal yaitu perlunya peningkatan informasi dan keterampilan intelektual

- Belum semua guru mengajarkan cara menyikat gigi karena masih merasa kesulitan dalam memberikan penyuluhan: tergolong faktor internal guru memerlukan persentuhan, repetisi, dan penguatan terhadap seseorang, Faktor perilaku yaitu perilaku seseorang atau masyarakat tentang kesehatan ditentukan oleh pengetahuan dan petugas kesehatan, Faktor eksternal yaitu perlunya peningkatan informasi dan keterampilan intelektual

- Suasana kelas kurang kondusif sehingga dilakukan penyuluhan ulang ke kelompok kecil: tergolong faktor eksternal yaitu perlunya peningkatan informasi dan keterampilan intelektual

- Murid kurang tertib sehingga guru kewalahan mengatur jalannya pelaksanaan: tergolong faktor internal siswa memerlukan persentuhan, repetisi, dan penguatan terhadap seseorang, faktor eksternal yaitu perlunya peningkatan informasi dan keterampilan intelektual, Faktor perilaku yaitu perilaku seseorang atau masyarakat tentang kesehatan ditentukan oleh pengetahuan dan petugas kesehatan

- prakteknya sulit, guru aktif menyampaikan meskipun belum sepenuhnya benar: tergolong faktor internal guru memerlukan persentuhan, repetisi, dan penguatan terhadap seseorang, faktor eksternal yaitu perlunya peningkatan informasi dan keterampilan intelektual, Faktor perilaku yaitu perilaku seseorang atau masyarakat tentang kesehatan ditentukan oleh pengetahuan dan petugas kesehatan

- Guru merasa ilmu yang dimiliki masih terbatas: tergolong faktor internal guru memerlukan persentuhan, repetisi, dan penguatan terhadap seseorang, faktor eksternal yaitu perlunya peningkatan informasi dan keterampilan intelektual, Faktor perilaku yaitu perilaku seseorang atau masyarakat tentang kesehatan ditentukan oleh pengetahuan dan petugas kesehatan

- Anak-anak sulit diatur dan tidak memperhatikan saat penyuluhan: tergolong faktor internal anak memerlukan persentuhan, repetisi, dan penguatan terhadap seseorang, faktor eksternal yaitu perlunya peningkatan informasi dan keterampilan intelektual, Faktor perilaku yaitu perilaku seseorang atau masyarakat tentang kesehatan ditentukan oleh pengetahuan dan petugas kesehatan

- Replika gigi di kelas tidak digunakan sehingga kurang terbayang sama anak-anak: tergolong faktor internal guru memerlukan persentuhan, repetisi, dan penguatan terhadap seseorang, faktor eksternal yaitu perlunya peningkatan informasi dan keterampilan intelektual, faktor perilaku yaitu perilaku seseorang atau masyarakat tentang kesehatan ditentukan oleh pengetahuan dan petugas kesehatan

- Tidak adanya cermin: tergolong faktor eksternal guru, faktor non perilaku yaitu ketersediaan fasilitas 
Majalah Kedokteran Gigi Indonesia. April 2017; 3(1): 15 - 22

ISSN 2460-0164 (print)

ISSN 2442-2576 (online)

\section{PEMBAHASAN}

Pengetahuan guru setelah pelatihan mengenai pemeliharaan gigi menunjukan rata rata berada pada kriteria baik. Sikap setelah pelatihan berada rata-rata berada pada kriteria baik. Tindakan guru dalam menyikat gigi berada pada kriteria baik. Hal ini sesuai dengan penelitian Mwangosi dan Nyandindi Tahun 2002 menyebutkan guru sekolah apabila diberi informasi secara umum mendapatkan informasi yang baik dan sikap serta tindakannya berada pada kriteria yang cukup baik. ${ }^{15}$

Hal tersebut di atas dapat terjadi karena guru memiliki sikap positif terhadap pendidikan kesehatan mulut untuk murid, sebagai bagian dari kurikulum pengajaran, namun, meskipun begitu masih ada beberapa dan memerlukan rekomendasi perbaikan..$^{15}$ Kekurangan yang penting, yang terdeteksi dan memerlukan rekomendasi perbaikan berdasarkan hasil observasi penelitian metode kuantitatif menunjukkan hasil pelatihan banyak dipengaruhi oleh faktor internal baik dari siswa maupun guru, sehingga memerlukan persentuhan, repetisi, dan penguatan terhadap guru serta faktor eksternal yaitu peningkatan informasi dan keterampilan intelektual dan ketersediaan fasilitas.

Hampir setengah responden yaitu sebesar $46,7 \%-66,7 \%$ masih melakukan tindakan pada kriteria cukup baik setelah pelatihan. Hal ini sesuai dengan penelitian Simon et all yang menyebutkan bahwa meskipun program pelatihan diterima dengan baik dan memasukkan teknik aplikasinya, namun masih ada tindakan yang belum berubah, karena adanya hambatan dalam diri responden, walaupun pada tingkat pendidikan yang tinggi. ${ }^{16}$

Uraian di atas menunjukkan pentingnya dukungan dari profesional dari tenaga kesehatan mulut atau perguruan tinggi seperti yang diungkapkan Mwangosi dan Nyandindi Tahun 2002 menyebutkan bahwa dukungan profesional dalam bentuk pelatihan pendidikan kesehatan mulut sangat diperlukan oleh guru, untuk mempersiapkan calon guru melaksanakan tugas masa depan mereka. ${ }^{15}$ Guru perlu dimotivasi untuk meningkatkan kesadaran mereka tentang informasi kesehatan mulut suara, sikap dan perilaku, sehingga dapat memudahkan peran guru sebagai penyelenggara pendidikan kesehatan mulut sekolah di sekolah dasar. Guru perlu dimotivasi untuk meningkatkan kesadaran mereka tentang informasi kesehatan mulut suara, sikap dan perilaku, sehingga dapat memudahkan peran guru sebagai penyelenggara pendidikan kesehatan mulut sekolah di sekolah dasar. ${ }^{15}$

Prosentase pengaruh variabel pengetahuan, sikap dan tindakan guru yang digunakan dalam model sebesar $18,5 \%$, sedangkan sisanya sebesar $81,5 \%$ dipengaruhi oleh variabel lain yang tidak dimasukkan ke dalam penelitian. Hasil penelitian Agostini et all ${ }^{17}$ menyebutkan bahwa persepsi orang tua berpengaruh terhadap persepsi anak terhadap perilaku kesehatan mulut anak, hal ini menunjukkan bukti bahwa psikososial adalah prediktor yang kuat dalam kesehatan gigi dan mulut anak-anak. ${ }^{2}$

Hasil uji simultan atau bersama sama ketiga variabel menunjukkan tidak ada pengaruh secara signifikan hasil pelatihan pada guru yang diukur melalui pengetahuan, sikap dan tindakan secara bersama sama terhadap status kebersihan mulut siswa. Hasil ini sesuai dengan penelitian D'Cruz dan Aradhya tahun 2013 menyebutkan bahwa keterlibatan aktif anak-anak sekolah dengan penguatan pendidikan kesehatan gigi dan mulut dapat meningkatkan pengetahuan kebersihan mulut, ${ }^{18}$ praktek dan kesehatan gingiva serta menurunkan tingkat plak.

Hasil di atas menunjukkan bahwa metode pelatihan yang digunakan dalam penelitian ini yang tidak berpengaruh terhadap ukuran kebersihan mulut dapat terjadi karena tidak melibatkan secara aktif anak-anak sekolah, dan hasil dari penelitian ini menunjukkan hasil yang sama dengan di atas yaitu memerlukan penguatan pendidikan kesehatan gigi dan mulut agar dapat meningkatkan praktik keterampilan menyikat gigi. ${ }^{18}$

Uji parsial menghasilkan ada pengaruh signifikan pada sikap guru terhadap status kebersihan mulut siswa, namun tidak ada pengaruh secara signifikan pada pengetahuan dan tindakan terhadap status kebersihan mulut siswa. Hasil ini sejalan dengan hasil penelitian Ehizele et all yang menyebutkan bahwa pola yang sama dapat terjadi dari kurang detilnya pengetahuan, tidak tepatnya 
tindakan. Penelitian tersebut menunjukkan bahwa guru sekolah dasar dapat berfungsi pendidik kesehatan gigi setelah mengikuti pelatihan terorganisir untuk meningkatkan pengetahuan kesehatan mulut mereka dan menyempurnakan tindakan mereka. ${ }^{19}$

Hasil di atas menunjukkan bahwa pengetahuan, sikap dan tindakan guru tidak berpengaruh terhadap status kebersihan mulut, dapat terjadi karena guru baru mendapatkan satu kali pelatihan, Hasil dari analisi kualitatif masih ditemukan belum semua guru mengajarkan cara menyikat gigi, karena masih merasa kesulitan dalam memberikan penyuluhan, guru merasa ilmu yang dimiliki masih terbatas. Hal ini sesuai dengan penelitian Bridges et all tahun 2014, menyebutkan bahwa pengetahuan pemberi materi sangat berhubungan dengan status kebersihan mulut. ${ }^{20}$

Hasil ini penelitian di atas menunjukkan bahwa pengetahuan, sikap dan tindakan guru tidak berpengaruh terhadap status kebersihan mulut. Hasil ini dapat terjadi juga karena faktor siswa. Penelitian Angeloupoulou tahun 2015 menyebutkan bahwa hambatan kebersihan mulut pada anak adalah kebosanan anak, rendahnya pengetahuan kesehatan mulut, dan pelupa. ${ }^{21}$

Hasil di atas dapat terjadi karena pemberian pendidikan kepada guru dan siswa dilakukan pada interval bulan ke enam. Penelitian shenoy dan Sequeira tahun 2010 menyebutkan program pendidikan kesehatan gigi dan mulut dalam meningkatkan pengetahuan kesehatan mulut, praktek, status kebersihan mulut, lebih efektif pada interval tiga minggu dibandingkan pada interval enam minggu. ${ }^{22}$

\section{KESIMPULAN}

Kesimpulan penelitian mixed method ini adalah pelatihan penyikatan gigi pada guru sekolah dasar sistem full day berpengaruh sebesar 18,5\% terhadap status kebersihan mulut siswa. Faktor penghambat menerapkan hasil pelatihan yaitu faktor internal dan eksternal guru dan siswa.

Saran berdasarkan hasil penelitian yaitu diperlukannya penguatan informasi dan keterampilan pada guru agar percaya diri dalam mentransfer hasil pelatihan kesehatan gigi serta penyediaan fasilitas pendukung oleh sekolah, Dinas Pendidikan dan Dinas Kesehatan setempat. Rekomendasi pengembangan penelitian yaitu meneliti dengan lengkap semua faktor yang berhubungan dengan pembentukan perilaku guru dan siswa agar dapat memperoleh model pelatihan yang tepat.

\section{UCAPAN TERIMA KASIH}

Ucapan terima kasih, kami sampaikan kepada Fakultas Kedokteran Gigi Univeritas Padjadjaran yang telah memberikan dukungan finansial berupa dana penelitian hibah unggulan fakultas, Kepala Sekolah, Guru dan Siswa SD Arraffi yang bersedia menjadi responden dalam penelitian ini.

\section{DAFTAR PUSTAKA}

1. Departemen Kesehatan Republik Indonesia. Laporan riset kesehatan dasar. Jakarta: Badan Penelitian dan Pengembangan Kesehatan; 2008. 134.

2. Kementerian Kesehatan. Pedoman usaha kesehatan gigi sekolah (Ukgs). Jakarta: Direktorat Bina Upaya Kesehatandasar Direktorat Jenderal Bina Upaya Kesehatan; 2012. 2, 30.

3. Newman MG, Takei H, Klokkevold PR, Carranza FA. Clinical Periodontology. Canada; Elsevier Saunders. Twelfth edition; 2015. 404.

4. Kementerian Kesehatan Republik Indonesia. Laporan Riset Kesehatan Dasar. Jakarta: Badan Penelitian Dan Pengembangan Kesehatan; 2013. 150 - 152.

5. Ehizele A, Chiwuzie J, Ofili A. Oral health knowledge, attitude and practices among Nigerian primary school teachers. International Journal of Dental Hygiene. 2011; 9(4): 254 260.

6. Sukiarko E. Pengaruh pelatihan dengan metode belajar berdasarkan masalah terhadap pengetahuan dan keterampilan kader kader gizi dalam kegiatan posyandu. 
Thesis. Semarang: Universitas Diponegoro. 2010. 112.

7. Solhi M, Zadeh DS, Seraj B, Zadeh SF. The application of health belief model in oral health education. Iranian J Publ Health. 2010; 39(4): $114-119$.

8. Marguireta J, Treadwell HM, Northridege M. Community health worker and community health choices: promoting good health. National Centre of Primary Care Morehosuse School of Medicine; 2003. 50.

9. Kwan SYL, Petersen PE, Pine CM, Borutta A. Health-promoting schools: An opportunity for oral health promotion. Bulletin of the World Health Organization. 2005; 83(9): $677-685$.

10. Sugiyono. Metode penelitian pendidikan: pendekatan kuantitatif, kualitatif, dan R\&D. Bandung: Alfabeta; 2010. 85, 149.

11. Arikunto S. Prosedur penelitian: suatu pendekatan praktek. Edisi VI. Jakarta: PT. Rineka Cipta; 2006. 20.

12. Komisi Nasional etik Penelitian Kesehatan. Pedoman Nasional Etik Penelitian Kesehatan RI. Jakarta: Depkes RI; 2007. 11.

13. Hiremath SS. Text book of preventive and community dentistry. 2nded. India: Reed Elsevier India Private Limited; 2011. 202.

14. Notoatmodjo S. Pendidikan dan ilmu perilaku. Jakarta: Rineka Cipta; 2007. 178.

15. Mwangosi I, Nyandindi U. Oral health related knowledge, behaviours, attitude and selfassessed status of primary school teachers in Tanzania. International dental journal. 2002; 52(3): $130-136$.
16. Simons D, Baker P, Jones B, Kidd E, Beighton D. An evaluation of an oral health training programme for carers of the elderly in residential homes. British Dental Journal. 2000; 188(4): $206-210$.

17. Agostini B, Machry R, Teixeira C, Piovesan C, Dutra M, Bresolin C, Ardenghi T. Selfperceived oral health influences tooth brushing in preschool children. Brazilian Dental Journal. 2014; 25(3): 248 - 252.

18. D'Cruz AM, Aradhya S. Impact of oral health education on oral hygiene knowledge, practices, plaque control and gingival health of 13- to 15-year-old school children in Bangalore city. Int J Dent Hyg. 2013; 11(2): 126 - 133. Epub 2012 Jun 30.

19. Ehizele A, Chiwuzie J, Ofili A. Oral health knowledge, attitude and practices among Nigerian primary school teachers. International Journal of Dental Hygiene. 2011; 9(4): 254 260.

20. Bridges SM, Parthasarathy DS, Wong HM, Yiu CK, Au TK, McGrath CP. The relationship between caregiver functional oral health literacy and child oral health status. Patient Educ Couns. 2014; 94(3): 411 - 416.

21. Angelopoulou M, Kavvadia K, Oulis C, Reppa $C$. Oral hygiene facilitators and barriers in greek 10 years old schoolchildren. Int $\mathrm{J}$ Clin Pediatr Dent. 2015; 8(2): 87 - 93.

22. Shenoy RP, Sequeira PS. Effectiveness of a school dental education program in improving oral health knowledge and oral hygiene practices and status of 12 to 13 year old school children. Indian J Dent Res. 2010; 21(2): 253 $-259$. 